\title{
CZY W POLSCE POTRZEBNY JEST NOWY KODEKS CYWILNY? ARTYKUŁ POLEMICZNY
}

\section{WPROWADZENIE}

W pierwszym zeszycie „Ruchu Prawniczego, Ekonomicznego i Socjologicznego" z tego roku ukazał się artykuł Jana Andrzejewskiego kwestionujacy potrzebę kodyfikacji prawa cywilnego w okresie „kryzysu prawa”. Autor, wychodząc z założenia, że nauka prawa cywilnego znajduje się w kryzysie, uzasadnia, że cywiliści powinni się zająć opracowaniem zasad prawa prywatnego, tworząc prawny „system ruchomy”, polegający na zasadach doprecyzowywanych przez orzecznictwo inspirowane poglądami doktryny. Autor jest zdania, że obecne prace legislacyjne prowadzą do tworzenia aktów prawnych zawierających normy szczegółowe, pełne rozwiązań mających na celu regulowanie powstających problemów praktycznych bez refleksji nad tym, jak należy regulować wątpliwe kwestie ogólne. W rezultacie powstał w Polsce trudny prawniczy metajęzyk zrozumiały tylko dla nielicznych oraz konserwatyzm metodologiczny prowadzacy do odrzucania nowych pomysłów. Obecny system sprzyja także pograż̇aniu się sądownictwa w kazuistyce wymuszanej przez nacisk na wydawanie szybkich orzeczeń, mieszczących się w zastanych ramach wytyczonych instrukcji.

Powyższa diagnoza nawiazuje do stanowiska przedstawionego w $2010 \mathrm{r}$. przez sędziów Izby Cywilnej SN² . Sędziowie SN uznali, że uchwalenie nowego kodeksu cywilnego nie jest potrzebne, gdyż:

- po pierwsze, nie wymaga tego potrzeba unifikacji prawa cywilnego;

- po drugie, obecny Kodeks cywilny w znacznej mierze przejmuje osiagnięcia polskiej myśli prawniczej utrwalone w Kodeksie zobowiązań. Kodeks w toku reform z lat dziewięćdziesiątych został oczyszczony z założeń nawiązujacych do ustroju socjalistycznego;

- po trzecie, obecny Kodeks jest dostatecznie przystosowany do potrzeb praktyki, która dobrze sobie radzi z jego wykładnią. Ustawodawca powinien się zatem zadowolić tylko nowelizacjami Kodeksu zharmonizowanymi z obecnymi jego przepisami;

${ }^{1}$ J. Andrzejewski, Czy nowa kodyfikacja prawa cywilnego jest potrzebna $w$ czasie kryzysu prawa?, „Ruch Prawniczy, Ekonomiczny i Socjologiczny” 2014, z. 1, s. 77 i n.

${ }^{2}$ Por. Projekt kodeksu cywilnego księga pierwsza. Sprawozdanie z dyskusji przeprowadzonej w Izbie Cywilnej Sądu Najwyższego, „Przegląd Sądowy” 2010, z. 2, s. 104 i n. 
- po czwarte, celem nowych przepisów nie powinno być rozstrzyganie istniejących wątpliwości prawnych oraz przenoszenie na grunt polski rozwiązań zagranicznych, gdyż nie jest pewne, czy warunki krajowe odpowiadają warunkom istniejacym w innych krajach.

Ostatecznie z dyskusji sędziów SN wynika wniosek, że nie ma potrzeby uchwalania nowego kodeksu, gdyż tylko obecny Kodeks gwarantuje stabilność prawa i jest dostosowany do wymagań obrotu gospodarczego. Kodeks nie budzi też zastrzeżeń merytorycznych ani językowych i powinien być jedynie stopniowo nowelizowany, aby dostosowywać go do aktualnych potrzeb, w tym do prawa Unii Europejskiej.

Ponieważ główny proponent idei nowego kodeksu cywilnego nie może sam zabrać głosu ${ }^{3}$, pozwalam sobie przypomnieć główne argumenty, które przemawiaja za uchwaleniem nowego kodeksu cywilnego wbrew prezentowanym powyżej stanowiskom.

1. Przede wszystkim kodeks cywilny, jak i inne kodeksy, jest aktem normatywnym szczególnego rodzaju, który ma stanowić wyczerpujące uregulowania pewnej dziedziny prawa. Taka regulacja ma także na celu usystematyzowanie takiej dziedziny, zdefiniowanie pewnych najważniejszych w niej zasad oraz stabilizację stanu prawnego gałęzi prawa.

2. Stabilizację stanu prawnego gwarantuja pewne ogólne założenia, na których zwykle kodeks się opiera, jak: zupełność kodeksu, czyli dążenie do ujęcia całej regulowanej dziedziny prawa, wyodrębnienie części ogólnej zawierającej zasady stosowane w całej gałęzi prawa, której kodeks dotyczy, uzasadniona merytorycznie systematyka oraz określony stosunek do pokrewnych działów prawa ${ }^{4}$.

3. Z powyższych względów konsolidacyjny i stabilizacyjny skutek kodyfikacji powinien odbijać się w dążeniu do unikania zbyt częstych nowelizacji i nieprzemyślanych zmian materii kodeksowej pod wpływem spektakularnych przypadków praktycznych, szeroko dyskutowanych przez prasę codzienną. W chwili obecnej kodeksy nie posiadają szczególnego statusu legislacyjnego, co należy ocenić negatywnie. Taki status mógłby się przykładowo wyrażać szczególnymi wymogami co do większości parlamentarnej mogącej uchwalić takie zmiany.

\section{ARGUMENTY NA RZECZ NOWEGO KODEKSU}

W rezultacie należy dojść do wniosku, że inicjowanie wysiłku zmierzającego do uchwalenia nowej kodyfikacji powinno mieć miejsce dopiero wtedy, gdy system polityczny, gospodarczy i społeczny, w którym kodeks ma funkcjono-

\footnotetext{
${ }^{3}$ Por. wypowiedź Z. Radwańskiego, Kodyfikacja prawa cywilnego, „Ruch Prawniczy, Ekonomiczny i Socjologiczny” 2009, nr 9, s. 134 i n.; idem, Uwagi do sprawozdania z dyskusji przeprowadzonej w Izbie Cywilnej Sadu Najwyższego nad „Projektem kodeksu cywilnego. Księa Pierwsza”, „Przegląd Sądowy” 2010, nr 5, s. 5 i n.

${ }^{4} \mathrm{~W}$ odniesieniu do kodeksu cywilnego chodzi np. o takie działy, jak: prawo handlowe, prawo pracy, prawo własności intelektualnej, prawo bankowe.
} 
wać, jest dostatecznie ustabilizowany. Jest oczywiste, że ocena, czy taka stabilizacja ma miejsce, jest trudna i zawsze wywoływać może dyskusje. Przedstawione powyżej uwagi krytyczne kierowane pod adresem autorów projektu kodeksu cywilnego dobrze ilustrują występujące w praktyce wątpliwości. J. Andrzejewski uważa, że znajdujemy się w okresie „kryzysu prawa”, który sprawia, że wszelkie próby kodyfikacyjne są przedwczesne i skazane na niepowodzenie. Autor nie wyjaśnia nam bliżej, na czym ten „kryzys prawa” polega, ale sądzić można, że chodzi mu o to, iż mamy obecnie znaczący nacisk zewnętrzny z Unii Europejskiej wymagajacy stałych wysiłków harmonizacyjnych. „Kryzys” wywołują także zapewne coraz częściej występujące stany faktyczne wymagające pilnie decyzji, na które brak wystarczających odpowiedzi w przepisach obowiązującego Kodeksu cywilnego. Warto zauważyć, że w przytoczonych powyżej wypowiedziach sędziów SN znajdujemy całkowicie odmienną ocenę sytuacji. Sędziowie bowiem zdają się uważać obecny stan prawny $\mathrm{w}$ dziedzinie prawa cywilnego za na tyle ustabilizowany i pewny, że nie wymaga on zasadniczych zmian i wystarczy do rozwiązywania problemów twórcza działalność orzecznictwa, w tym Sądu Najwyższego.

Jak widać, ocena obecnej sytuacji prawnej w dziedzinie prawa cywilnego może być odmienna w zależności od przyjętych założeń wstępnych prowadzonego rozumowania. Jednakże wydaje się, że zarówno system polityczny, jak i gospodarczy i społeczny w Polsce osiagnęły już taki poziom stabilizacji, który sprzyja kodyfikacji prawa cywilnego. W szczególności wskazać należy na mijajacy w roku 2014 dziesięcioletni już okres niezakłóconego uczestnictwa naszego kraju w Unii Europejskiej i związane z nim formowanie się systemu prawa uwzględniającego w szerokim zakresie także prawo Unii Europejskiej.

\section{OBECNY STAN KODEKSU}

Obecnie obowiązujący Kodeks cywilny został uchwalony 23 kwietnia $1964 \mathrm{r}$. Jest to akt prawny wiodaccy w całej dziedzinie prawa prywatnego. Zawiera on bowiem ogólne zasady prawa prywatnego, które znajdują zastosowanie w sprawach nieunormowanych przez inne kodeksy i ustawy prawa prywatnego materialnego ${ }^{5}$. Tak jest w szczególności w odniesieniu do Kodeksu rodzinnego i opiekuńczego, Kodeksu pracy, Kodeksu spółek handlowych, Kodeksu morskiego, Prawa autorskiego i praw pokrewnych, Prawa własności przemysłowej, Prawa bankowego i innych ustaw szczegółowych. Stąd też jest bardzo ważne, aby Kodeks cywilny odpowiadał aktualnym potrzebom. Tymczasem wbrew opinii sędziów SN jego stan obecny nie jest zadowalajacy. Jest to wynikiem szeregu czynników.

Kodeks cywilny został uchwalony w okresie „dojrzałego” socjalizmu. Jest prawda, że nie był on pozbawiony dorobku polskiej myśli prawniczej z okresu międzywojennego, jednakże na ten dorobek zostały nałożone rozwiązania charakterystyczne dla gospodarki socjalistycznej, które widoczne były zwłaszcza

\footnotetext{
${ }^{5}$ Por. uwagi Z. Radwańskiego, Kodyfikacja prawa..., s. 133-135.
} 
w części ogólnej, prawie rzeczowym, spadkowym i rodzinnym. Reforma Kodeksu cywilnego z 1990 r. ${ }^{6}$ w znacznej mierze „wyczyściła” go z tych naleciałości ${ }^{7}$, zostawiając jednakże w jego tekście dotkliwe luki, szczególnie widoczne w prawie rzeczowym (np. art. 126-139) czy w prawie spadkowym (art. 1059-1088). Zmiany dokonywane w k.c. w latach dziewięćdziesiątych były ponadto wprowadzane pod naciskiem okoliczności im towarzyszacych i z reguły brak w nich było spojrzenia na całość kodeksu. Podobnie było ze zmianami związanymi z naszym przystapieniem do Unii Europejskiej, wprowadzającymi przepisy o ochronie konsumentów ${ }^{8}$, które znaczną ich część pozostawiaja poza tekstem Kodeksu ${ }^{9}$. W takich przypadkach następuje zjawisko dekodyfikacji materii, która powinna znajdować się w jego tekście, a jest obecnie uregulowana poza nim. Do takich dotkliwych braków w tekście Kodeksu zaliczyć można ponadto szereg kwestii dotyczących osób prawnych, praw do lokali, włączenia zagadnień własności intelektualnej czy czynności prawa bankowego.

Dekodyfikacja prawa cywilnego prowadzi do szeregu niekorzystnych zjawisk w dziedzinie legislacji.

Po pierwsze, przepisy Kodeksu przestaja informować o istotnych elementach regulowanej instytucji prawnej. Przykładowo w przepisach k.c. nie można obecnie znaleźć wzmianki o tym, że do powstania i przeniesienia wieczystego użytkowania potrzebny jest konstytutywny wpis w księdze wieczystej. Podobnie nie są ujęte w Kodeksie zagadnienia związane z formą elektroniczna oświadczenia woli. Rodzi to wątpliwości co do tego, czy jest to tylko jedna z postaci formy pisemnej, czy także forma odmienna od formy pisemnej.

Po drugie, w ustawach pozakodeksowych używana jest często terminologia odmienna od tej, którą posługuje się ustawodawca w Kodeksie, chociaż stanowi on podstawową regulację w sferze cywilnoprawnej i terminologia w nim użyta powinna być także stosowana w aktach prawnych poza Kodeksem. Przykładem może być terminologia sprzedaży konsumenckiej, w której zamiast pojęcia „wada rzeczy” używa się określenia „niezgodność towaru z umową".

Po trzecie, ustawy pozakodeksowe posługują się nieraz terminologią użyta w Kodeksie, ale nadająjej inny sens. Tak jest w szczególności w sprawie odstąpienia od umowy przez konsumenta, w której odstapienie przez konsumenta staje się skuteczne już z chwilą wysłania oświadczenia w terminie ustawowym, co nie znajduje odbicia w Kodeksie cywilnym. W tej samej ustawie w postanowieniach dotyczacych usług finansowych prawo konsumenta do odstapienia od umowy ma być wykonane przez złożenie oświadczenia w terminie 14 dni od zawarcia umowy (art. 16c) albo 30 dni od informacji o zawarciu umowy. W tym przypadku jednak brak przepisu nakazującego traktować oświadczenie jako złożone już z chwilą jego wysłania, co rodzi wątpliwości interpretacyjne mimo odesłania zawartego w art. 16e tej ustawy. Brak jest zatem ogólnej re-

\footnotetext{
${ }^{6}$ Dz. U. 1990, Nr 55, poz. 321.

7 Por. uwagi Z. Radwańskiego i A. Olejniczaka w: Prawo cywilne - część ogólna, Warszawa 2011, s. 28-29.

8 Por. Dz. U. 2000, Nr 22, poz. 271.

9 Por. ustawa z 2 marca 2000 r. o ochronie niektórych praw konsumentów i o odpowiedzialności za szkodę wyrządzoną przez produkt niebezpieczny (t.jedn.: Dz. U. 2012, poz. 1225).
} 
guły kodeksowej dotyczącej szczególnych zasad odstapienia od umowy przez konsumenta, co wywołuje wskazane wyżej wątpliwości.

Po czwarte, do regulacji szczegółowych wprowadzane sa przepisy niejasno określające stosunek tych uregulowań do k.c. Taki przykład znajdujemy już w samym tekście k.c. skutkiem wprowadzenia do jego przepisów postanowień o odpowiedzialności za produkt. Gdy chodzi bowiem o szkodę na osobie, art. $449^{10}$ ogranicza się do odesłania do odpowiedzialności za szkodę na zasadach ogólnych, co oznacza odesłanie do art. 415 k.c., a nie do przepisów art. 444-448 k.c., o które w tym przypadku przede wszystkim chodzi. Podobnie w Prawie autorskim znajdujemy przepis art. 79 ust. 1 pkt 3 nakazujacy naprawić szkodę na zasadach ogólnych albo przez zapłatę sumy pieniężnej odpowiadającej dwukrotności, a gdy naruszenie jest zawinione - trzykrotności stosowanego wynagrodzenia należnego z tytułu udzielenia licencji. Przepis ten rodzi wątpliwości, czy można wyrównać szkodę na zasadach ogólnych (tj. na podstawie art. 415 k.c.) bez wykazania winy naruszającego prawo.

\section{WPLYW PRAWA UNII EUROPEJSKIEJ}

Brak kodeksu cywilnego w pełni dostosowanego do aktualnych warunków rodzi szereg trudności związanych z implementacją dyrektyw Unii Europejskiej. Dyrektywa wymaga wydania przepisów ją wprowadzajacych we wskazanym w niej terminie. Jest oczywiste, że nie można również wydawać przepisów kolidujących z dyrektywą oraz należy dążyć do wychwycenia i uchylenia przepisów z dyrektywą sprzecznych, jeżeli znajdują się one w kodeksie. Istnienie kodeksu rodzi pytanie, w jaki sposób wdrażać przepisy dyrektyw, jeżeli dotyczą one materii w nim poruszanej. Możliwe są tutaj trzy rozwiąania.

Pierwsze, polega na nieomal dosłownym przełożeniu dyrektywy na polski język prawny i wydanie odrębnej ustawy. Tak postapił ustawodawca w takich sprawach, jak sprzedaż konsumencka, kredyt konsumencki, terminy zapłaty w stosunkach handlowych. Przyjęto w tych przypadkach pogląd, że instytucje nowe, nieznane w k.c. i nie całkiem jeszcze ukształtowane w prawie Unii Europejskiej można regulować w ustawach pozakodeksowych. W takim przypadku konieczne jest jednak określenie stosunku nowej ustawy do kodeksu, gdyż w braku takiego określenia obowiąuje relacja lex specialis - lex generalis, która oznacza w zasadzie wyłączenie przez nową ustawę postanowień kodeksowych. Konsekwencja ta nie zawsze jest jednak zamierzona przez projektodawcę przepisów implementujących. Stwarza ona także szereg wątpliwości innej natury. Mianowicie dyrektywy oparte są w wielu przypadkach na nowych rozwiązaniach prawnych, które w braku inkorporacji do postanowień k.c. mogą doprowadzić do marginalizacji kodeksu jako nieodzwierciedlającego nowych konstrukcji prawnych, właściwych prawu europejskiemu. Przykładu może dostarczyć wspomniany powyżej przypadek konsumenckiego prawa odstapienia od umowy, któremu z braku ogólnego ujęcia kodeksowego brak 
spójności z ogólnymi przepisami k.c. Rozbieżność koncepcji, na której opiera się k.c., i szczegółowe przepisy implementujace prawo unijne prowadzą do nieuchronnych trudności interpretacyjnych, którym zapobiec może tylko modernizacja przepisów k.c.

Drugą i zalecaną koncepcją wprowadzania przepisów dyrektyw do k.c. jest dążenie do włączenia do niego od samego początku przepisów wdrażających dyrektywę. Tego rodzaju rozwiązanie przedstawia największe zalety. Przede wszystkim wymaga dostosowania przepisów implementacyjnych do całości kodeksu, a dotyczy to zarówno terminologii, jak i przejmowanych z dyrektyw konstrukcji prawnych. Metoda ta jest jednak czasochłonna w zestawieniu z metodą wydawania odrębnej ustawy i ponadto wymaga dostosowania całego aktu prawnego do nowelizacji implementacyjnej, co także jest trudne i nieraz dyskusyjne. Przykładowo należy wskazać wspomniane wyżej włączenie do k.c. przepisów o odpowiedzialności za produkt, w którym pominięto regulację szkód na osobie.

W wielu przypadkach zatem jedyną właściwą metodą wdrażania dyrektywy do k.c. będzie droga stopniowego włączania doń przepisów implementujących. Polega ona na wydaniu w pierwszej kolejności ustawy szczególnej wprowadzającej dyrektywę, a następnie włączenie jej do kodeksu. Jest zrozumiałe, że wydawanie takiej ustawy jest tylko pierwszym krokiem w kierunku włączenia postanowień dyrektywy do kodeksu i dlatego prace w kierunku takiego włączenia powinny być prowadzone nieprzerwanie najlepiej przez to samo gremium, które opracowało ustawę implementacyjna. Często przeszkoda $\mathrm{w}$ prowadzeniu takich prac jest resortowe podejście do legislacji, które wyraża się tym, że na przykład niektóre kwestie dyrektyw konsumenckich należą do kompetencji legislacyjnej ministra sprawiedliwości, a niektóre do Urzędu Konkurencji i Konsumentów. W takich przypadkach implementacja rodzi problemy koordynacyjne między poszczególnymi resortami, które są często trudne do przezwyciężenia. Często trudności te wynikają także z różnych jej koncepcji we właściwych resortach.

Włączanie przepisów wprowadzających dyrektywy do k.c. rodzi jeszcze jedną trudność wartą wzmianki. Jest całkowicie jasne, że włączając dyrektywę do kodeksu nie można jej odtworzyć dosłownie i jej tekst wymaga dostosowania do takiego kompleksowego aktu prawnego, a także i kodeks wymaga dostosowania do przepisów wdrażających. W takim przypadku powstają w organach Unii Europejskiej często wątpliwości, czy implementacja krajowa przeprowadzona jest prawidłowo i dokładnie. Często zdarzają się pytania o brak przejęcia pewnych konstrukcji czy sformułowań. W takim przypadku osoby opracowujące projekty muszą być przygotowane na dostarczenie właściwych odpowiedzi - wskazanie ogólnych przepisów kodeksowych rozstrzygających wątpliwości podnoszone przez Komisję Europejską.

Oprócz dyrektyw sposobem na ujednolicanie prawa w Unii Europejskiej są także rozporządzenia. W dziedzinie prawa prywatnego występują one rzadko, z reguły w sferze prawa handlowego. Jest oczywiste, że jeżeli wydane jest rozporządzenie, to przepisy krajowe sprzeczne z jego przepisami muszą być usunięte z tekstu kodeksu, a zanim to nastapi, nie powinny być co najmniej stosowane. Podobnie nie jest dopuszczalne wydawanie nowych przepisów, które mogłyby kolidować z przepisami rozporządzeń. 
Szczególnie dyskusyjne są w prawie unijnym wydawane przez Komisję Europejską rozporządzenia wykonawcze do dyrektyw. Tego rodzaju rozwiązanie powoduje usztywnienie możliwości wdrożenia dyrektywy, gdyż rozporządzenie wykonawcze do niej jest bezpośrednio stosowalne, co w jakimśs zakresie narzuca także sposób implementacji takiej dyrektywy jako całości. Podobnie zakres swobody implementacji dyrektywy jest w znacznej mierze ograniczony przy dyrektywach wychodzacych z założenia tzw. harmonizacji maksymalnej, której przykładem jest dyrektywa o nieuczciwych praktykach handlowych.

Wszystkie powyższe trudności nie stanowia jednak przeszkody w uznaniu za właściwą metody włączania przepisów implementujących dyrektywy bezpośrednio do k.c.

\section{STABILNOŚĆ KODEKSU}

Poważną wadą z punktu widzenia stabilności systemu prawnego jest zbyt częsta nowelizacja kodeksów. Nie licząc zmian będących następstwem innych ustaw, Kodeks cywilny na przykład był zmieniany ponad 50 razy, Kodeks postępowania cywilnego - blisko 100 razy. Bardzo liczne zmiany prowadzą do tego, że zmniejsza się zrozumiałość tekstu k.c. Wiele z tych zmian ma charakter fragmentaryczny i wywołany przez konkretne przypadki praktyczne, co podważa stabilność k.c.

Warto wreszcie zauważyć, co już powyżej sygnalizowałem, że liczne sa kompleksowe ustawy pozakodeksowe zawierajace istotną materię słabo powiązana z k.c. Do takich kompleksowych ustaw noszących zwykle nazwę „prawo” należą zwłaszcza Prawo bankowe, Prawo własności przemysłowej, Prawo autorskie i prawa pokrewne. Niewątpliwie przyszła kodyfikacja powinna stworzyć „pomost” legislacyjny między k.c. a szczegółowymi ustawami, które obecnie sa zbyt słabo z nim powiązane. Kodeks cywilny powinien w nowej wersji otworzyć się także na problemy powstające w związku z rozwojem technik elektronicznego świadczenia usług i zawierania umów drogą elektroniczna.

\section{WNIOSKI}

W konkluzji należy stwierdzić, że uchwalenie, i to w stosunkowo szybkim tempie, nowego kodeksu cywilnego jest koniecznym i pilnym zadaniem legislacyjnym. Kodeks dostostosowany do aktualnych warunków niewątpliwie pozwoli znacznie bardziej efektywnie przyswajać w polskim systemie prawnym dyrektywy unijne, gdyż jego tekst będzie odzwierciedlał aktualny poziom rozwoju prawa prywatnego w Europie i na świecie.

Jeżeli przez „kryzys prawa” rozumieć okres, w którym zachodzą i będa zachodzić dość dynamiczne zmiany ustawodawcze w prawie cywilnym, to niewątpliwie podstawa, na którą zmiany te będą się nakładać, powinien być nowoczesny i dostosowany do obecnego etapu rozwoju prawa cywilnego kodeks cywilny. Tylko do takiego kodeksu będzie można w sposób względnie logiczny 
i harmonijny włączać co bardziej istotne zmiany wynikające z ewolucji prawa Unii Europejskiej, zamiast pozostawiać je poza kodeksem w postaci odrębnych ustaw.

Postulatu orzekania w istotnych dla prawa cywilnego sprawach zgodnie z bliżej nieokreślonymi „zasadami prawa” nie da się zrealizować w praktyce, gdyż w chwili obecnej nie wiemy nawet, jak te zasady nazywać. W Kodeksie i innych ustawach używa się zamiennie terminu „zasady współżycia społecznego”, „dobre obyczaje”, „zasady słuszności” bez pełnej wiedzy, czy terminy te są tożsame. Już samo to spostrzeżenie powinno prowadzić do dążenia w kierunku ujednolicania terminologii kodeksowej i innych ustaw.

Wiele kwestii uregulowanych $\mathrm{w}$ ustawach szczególnych powinno znaleźć swoje miejsce w kodeksie cywilnym, albo też ustawy te powinny zostać bliżej z nim powiązane. Niewątpliwie piąta księge Kodeksu powinna stanowić problematyka prawa rodzinnego, która ciagle tworzy odrębny Kodeks rodzinny i opiekuńczy, chociaż nie ulega wątpliwości, że prawo rodzinne jest coraz bardziej nabierająca znaczenia częścią prawa cywilnego. Także postulat wchłaniania nowych rozwiązań prawnych głównie przez ewolucję orzecznictwa, wypływający z krytycznych wypowiedzi sędziów Sądu Najwyższego, nie może być właściwą recepta na „kryzys” prawa cywilnego. Orzecznictwo to bowiem opiera się na precedensie, a ten zaś z natury rzeczy dostosowany jest do konkretnego przypadku, który sąd ma rozwiązać. Opieranie postępu prawa na precedensach prowadzi często do rozstrzygnięć, którym brak teoretycznej spójności. Próby tworzenia na tej bazie racjonalnego systemu prawnego sa niezmiernie trudne i w zasadzie skazane na niepowodzenie. W naszej kulturze prawnej orzecznictwo powinno się opierać na podbudowanych teoretycznie normach prawnych. Odwrócenie tej zależności prowadziłoby zapewne do jeszcze większej niestabilności prawa, niż to ma miejsce obecnie.

prof. dr hab. Marian Kepiński

Uniwersytet im. Adama Mickiewicza w Poznaniu

kpe@amu.edu.pl

DOES POLAND NEED A NEW CIVIL CODE?

Summary

This article is a polemics with opinions expressed in legal literature and practice that argue that there is no need for drafting a new Polisch civil code. The author claims that the frequent the amendments to the civil code that have been made after the structural transformation in the 1990s have brought about such substantial changes that it no longer fulfils the requirements of a one and complete regulation of the entirety of civil law relations. The amendments implemented in response to the current needs have practically led to de-codification of the Civil Code matter. What is more, the current Code lacks necessary modifications needed to include in it new legal solutions and ideas. This is true, in particular, of consumer law and professional contracts. The practice of law cannot be merely based on precedents, or general principles of law as it would be contrary to the traditions of Polish civil law. A modern, up-to-date code would also facilitate implementation of the European Union law into the system of Polish private law. 
Copyright of Journal of Law, Economics and Sociology is the property of Faculty of Law and Administration of Adam Mickiewicz University in Poznan and its content may not be copied or emailed to multiple sites or posted to a listserv without the copyright holder's express written permission. However, users may print, download, or email articles for individual use.

Właścicielem praw autorskich do „Ruchu Prawniczego, Ekonomicznego i Socjologicznego” jest Wydział Prawa i Administracji Uniwersytetu im. Adama Mickiewicza w Poznaniu. Zawartość czasopisma nie może być kopiowana, przesyłana do innych stron internetowych bądź zamieszczana na blogach bez pisemnej zgody wydawcy. Niemniej artykuły można drukować, kopiować lub przesyłać w formie elektronicznej na własny użytek. 